\title{
Cover crops of oats, stooling rye and three annual ryegrass cultivars influence maize and Cyperus esculentus growth
}

\author{
S R BEZUIDENHOUT*, C F REINHARDT $\dagger \&$ M I WHITWELL*
}

* KwaZulu-Natal Department of Agriculture, Environmental Affairs and Rural Development, Private Bag X9059, Pietermaritzburg 3200, South Africa, $\dagger$ Department of Plant Production and Soil Science, University of Pretoria, Pretoria 0002, South Africa

Running head: Cover crop residues suppress weed and crop growth

Correspondence: Suzette Bezuidenhout, KwaZulu-Natal Department of Agriculture, Environmental Affairs and Rural Development, Private Bag X9059, Pietermaritzburg 3200, South Africa. Tel: (+27) (0)33 355 9408; Fax: (+27) (0)33 355 9498; E-mail: suzette.bezuidenhout@kzndae.gov.za

\section{Summary}

No information is available on the effect of cover crops on weed growth in maize production in KwaZulu-Natal, South Africa. In a field experiment, the influence of two preceding cover crops, stooling rye and annual ryegrass, on the growth of maize and the weed Cyperus esculentus were compared with herbicides and weed control by hoeing. Maize emergence and early growth were delayed in the presence of physical residues of both cover crop species, especially in annual ryegrass residues. Growth of C. esculentus was significantly inhibited in the inter-row maize planting lines by the cover crops for the first 16 days after maize emergence, but this effect had diminished by day 28. In a pot experiment, the influence of the same two cover crops on maize and C. esculentus growth was evaluated together with oats and two additional annual ryegrass cultivars. Here the growth of maize and C. esculentus growth was suppressed, especially by the root residues of the annual ryegrass, in particular the cultivar Midmar. Chemical analysis of the leachate of the root residues indicated the presence of phenolic acids and benzoxazolin-2(3H)-one (BOA). In order to achieve effective weed control, a weed management strategy combining the mulch retained on the soil surface with a possible reduction in the type and amount of herbicide(s) should be implemented.

Keywords: allelopathy, allelochemicals, crop management, weed suppression 


\section{Introduction}

Maize (Zea mays L.) produced in the province of KwaZulu-Natal (KZN) accounts for only $4.6 \%$ of the total maize production in South Africa. However, it forms part of the agricultural activities that provide $60 \%$ of the rural population in the province with food security and a sole or complementary income. Weed interference is a given in any crop production situation, leading to potentially high yield losses if the weeds are not adequately controlled (Halford $e t$ al., 2001). Environmental and health concerns with regards to herbicide use stimulated the renewed interest into cultural weed control research (Kruidhof et al., 2008). Ryan et al. (2009) found that the yields of crops growing in organic systems, which depended more on cultural weed control methods, were also not compromised by higher weed biomass levels. Cover crop residues can suppress weed growth through changes in microclimatic conditions, the creation of a physical barrier to growth (Teasdale \& Mohler, 2000) and due to allelopathy (Olofsdotter et al., 2002). The level of weed suppression will depend on the cover crop species, the amount and thickness of the mulch and the management system used (Creamer et al., 1996). Cultivars of the same cover crop differ, not only in terms of their general weed suppression abilities, but also through the reduction of growth of specific weed species (Vasilakoglou et al., 2006). Dhima et al. (2006) found that stooling rye (Secale cereale L.) and barley (Hordeum vulgare L.) reduced the emergence of Echinochloa crus-galli L. (barnyard grass) and Setaria verticillata L. (bristly foxtail) by $27-80 \%$ and $0-67 \%$ respectively, in comparison to non-residue plots.

In KZN province, Cyperus esculentus L. (yellow nutsedge) can become dominant and difficult to control in a conservation tillage system, reducing the yields of maize (Stoller $e t$ al., 1979), cotton (Gossypium hirsitum L.) (Moffett \& McCloskey, 1998) and vegetables (Johnson III \& Mullinix Jr, 1999) through competition (Stoller et al., 1979) and allelopathy (Drost \& Doll, 1980). Incorporating shading by cover crop residues as part of an integrated weed management system could be beneficial, as shade is known to be an effective inhibitor of C. esculentus growth (Li et al., 2001).

Limited work has been done in South Africa on the ability of cover crops to suppress weed growth. Fourie et al. (2006) evaluated different cover crops for weed control in vineyards in the Western Cape. Little and van Staden (2003) have done work on the use of legumes to suppress weed growth in forestry and most recently, Ferreira and Reinhardt 
(2010) explored the possibility of using allelopathic crop residues to suppress herbicide resistant weeds in the Western Cape. The hypothesis tested in the present study was that annual ryegrass and stooling rye, used as winter grown cover crops, could suppress $C$. esculentus growth without compromising the growth of maize.

\section{Materials and Methods}

\section{Field experiment}

A field experiment was conducted from 2003 to 2007 at the Cedara Research Centre of the KZN Department of Agriculture, Environmental Affairs and Rural Development (latitude $29^{\circ} 32$ 'S; longitude $30^{\circ} 16^{\prime} \mathrm{E}$; altitude $1051 \mathrm{~m}$ ). The soil consisted of $37 \%$ clay, $20 \%$ silt, $43 \%$ sand and $2.59 \%$ organic matter. Three control treatments, namely herbicide (pre- and postemergence), hand-weeded (hoeing) and non-weeded were replicated four times in a randomized block design. Stooling rye cv. Agri Blue and annual ryegrass cv. Midmar were drilled in autumn at 30 and $90 \mathrm{~kg} \mathrm{ha}^{-1}$ respectively, at a spacing of $150 \mathrm{~mm}$ in the row. After seeding, nitrogen $\left(350 \mathrm{~kg} \mathrm{ha}^{-1}\right)$, phosphorus $\left(20 \mathrm{~kg} \mathrm{ha}^{-1}\right)$ and potassium $\left(160 \mathrm{~kg} \mathrm{ha}^{-1}\right)$ were applied as NPK (2:3:4) (40\%), with $0.5 \%$ added zinc. The balance of nitrogen $\left(336 \mathrm{~kg} \mathrm{ha}^{-1}\right)$ was applied as a top-dressing in the form of limestone ammonium nitrate (28\%) and potassium $\left(133 \mathrm{~kg} \mathrm{ha}^{-1}\right)$ as potassium chloride $(\mathrm{KCl})$ six weeks after cover the planting of the cover crops. Glyphosate-isopropylamine (Roundup SL, $360 \mathrm{~g}$ a.i. $\mathrm{L}^{-1}$, Monsanto) was applied at $2160 \mathrm{~g}$ a.i. $\mathrm{ha}^{-1}$ directly after planting with a knapsack at $200 \mathrm{kPa}$ using a floodjet nozzle (Lurmark Polijet $110^{\circ}$ AN1.8) to kill existing weeds. No additional herbicide applications were made thereafter. The two cover crops were grown until maturity at 23 weeks, and then killed with glyphosate-isopropylamine as before.

In spring, the plots grown to the two cover crops were prepared for growing maize. The pre-emergence herbicide combination of S-metolachlor (Dual S Gold EC, $915 \mathrm{~g}$ a. i. L ${ }^{-1}$, Syngenta) and atrazine/terbuthylazine (Suprazine SC, 300/300 g a.i L ${ }^{-1}$, Dow AgroScience) was applied at 1189.5 and $1200 \mathrm{~g}$ a.i. $\mathrm{ha}^{-1}$ respectively, at planting with a knapsack sprayer equipped with a floodjet nozzle as before. The post-emergence herbicides paraquat dichloride (Gramoxone, SL, $200 \mathrm{~g}$ a.i. $\mathrm{L}^{-1}$, Syngenta) and ametryn (Ametryn 500 SC, $500 \mathrm{~g}$ a.i. $\mathrm{L}^{-1}$, Dow AgroScience) applied at 600 and $1000 \mathrm{~g}$ a.i. ha $^{-1}$ respectively, with an even flat fan nozzle (Teejet TP 8003E) at $200 \mathrm{kPA}$, were applied six weeks later. Hand-weeding was done as soon as $5 \%$ visual weed cover occurred. In the non-weeded control plots no manual or 
chemical weeding was done. Maize cv. PHB 32D99, was hand-seeded at 44444 seeds ha $^{-1}$ in $0.75 \mathrm{~cm}$ spaced planting lines drawn with a $\mathrm{V}$-shaped hoe into the residues in spring. Nitrogen $\left(140 \mathrm{~kg} \mathrm{ha}^{-1}\right)$ and phosphorus $\left(20 \mathrm{~kg} \mathrm{ha}^{-1}\right)$ were applied as NPK (2:3:4) (40\%) with $0.5 \%$ added zinc and the balance of nitrogen $\left(110 \mathrm{~kg} \mathrm{ha}^{-1}\right)$ was applied as a top-dressing in the form of limestone ammonium nitrate (28\%) five weeks after maize planting. Soil analysis indicated that potassium levels were adequate and therefore no additional potassium was needed.

The plots were $18 \times 6 \mathrm{~m}$ in size with maize measurements taken on four data rows. The date of final maize emergence was the last day emergence was measured and expressed as the percentage of seeds planted. Maize seedlings were cut at the soil surface at 14, 28 and 44 days after emergence (DAE). During 2003-2005 C. esculentus growth was only visually assessed but in 2006 and 2007 the leaf mass of $C$. esculentus was measured to obtain a more quantitative measurement. Leaf material of $C$. esculentus was collected separately in interand intra-row maize planting lines in six $0.09 \mathrm{~m}^{2}$ blocks and the dry weights recorded at 16 , 28 and 41 (DAE). Maize yields were determined five months after planting.

The data were analysed using the analysis of variance (ANOVA) procedure in the statistical package Genstat (Payne et al., 2007) with terms for method of weed control. Treatment means were compared using Fisher's Protected Least Significant Difference procedure $\mathrm{P} \leq 0.05$.

\section{Pot experiment}

Anecdotal evidence of poor crop establishment in different annual ryegrass cultivar residues and weed suppression by oats (Avena sativa L.) emanating from the local farming community, plus previous research done on the suppression abilities of different cover crop species (Norsworthy et al., 2007) and cultivars (Reberg-Horton et al., 2009) prompted the inclusion of oats and two additional annual ryegrass cultivars to elucidate the results from the field experiment.

An experiment was carried out in 2009 in a temperature-controlled plastic tunnel. Plastic pots (195 mm diameter, $200 \mathrm{~mm}$ in height) were filled with four kilograms of sand consisting of $4.95 \%$ clay $(<0.002 \mathrm{~mm}), 3.29 \%$ silt $(0.002-0.05 \mathrm{~mm})$ and $91.76 \%$ sand $(0.05-2 \mathrm{~mm})$. 
Nitrogen $\left(350 \mathrm{~kg} \mathrm{ha}^{-1}\right)$, phosphorus $\left(95 \mathrm{~kg} \mathrm{ha}^{-1}\right)$ and potassium $\left(250 \mathrm{~kg} \mathrm{ha}^{-1}\right)$ were applied as solid NPK 2:3:4 (30\%) fertilizer with $0.5 \%$ added zinc according to recommendations for annual ryegrass establishment. The balance of nitrogen $\left(286 \mathrm{~kg} \mathrm{ha}^{-1}\right)$ was applied as limestone ammonium nitrate (28\%) and potassium $\left(123 \mathrm{~kg} \mathrm{ha}^{-1}\right)$ as potassium chloride (50\%). Water draining out of the pots was collected in pots lined with a clear plastic bag which was then used to water the same pots again. In this way, the nutrient solution was recirculated in order to minimise variation in nutrition and putative allelochemicals exuded through the roots.

Four treatments were replicated 10 times in a randomized block design. Three cover crop species, stooling rye cv. Agri Blue, oats cv. Heros and three annual ryegrass cultivars Agriton, Midmar and Sophia were planted according to the equivalent of their respective field-recommended seeding rates. No treatments were applied to the cover crops during their 21-week growth period, following which the cover crops were killed by spraying glyphosateisopropylamine (Roundup Turbo SL, $450 \mathrm{~g}$ a.i. $\mathrm{L}^{-1}$, Monsanto) at a rate of $2160 \mathrm{~g}$ a.i. ha ${ }^{-1}$, using a flat fan nozzle (Teejet XR $8002 \mathrm{VS}$ ) at $200 \mathrm{kPa}$. Four treatments were implemented two weeks after the cover cops were killed with glyphosate-isopropylamine. Treatment one (= leaf+root) consisted of the dead cover crop material left intact in the pots while for treatment two (= roots) the cover crop leaf material was cut at the soil surface and removed, leaving the roots intact. The desiccated foliage of the cover crops were weighed to obtain dry matter yields equivalent to $5 \mathrm{tha}^{-1}$ for the stooling rye and annual ryegrass and $4 \mathrm{tha}^{-1}$ for the oats. Pots filled with previously unused sand, treated in the same manner as described for establishing the cover crops, were used in treatment three and four. For treatment three (= leaf material) the weighed leaf material was placed on top of the sand while for treatment four (= soaked leaf material) the leaf material was first soaked overnight (24 hours) in tap water, then rinsed before being placed on top of the sand. The control consisted of unused sand with no cover crop residues. Ten maize seeds (Pioneer Seeds PHB 32D99) and ten $C$. esculentus tubers were planted separately into each of the four treatments.

The date of final maize and C. esculentus emergence was the last day emergence was measured and expressed as the percentage of seeds and tubers planted. Three weeks after planting, the foliage (stem and leaves) of the maize and the C. esculentus plants was sampled and oven-dried at $70^{\circ} \mathrm{C}$ for 48 hours to determine the dry weight. Chemical analysis for three phenolic acids, vanillic, ferulic and hydroxybenzoic acids and benzoxazolin-2(3H)-one 
(BOA) according to the methods of Wójcik-Wojtkowiak et al. (1990) and Nair et al. (1990) was carried out. A decision was made that in the light of unforeseen financial restrictions, chemical analysis would only be done on the leachate collected from the root treatment (Treatment 2) of the three annual ryegrass cultivars and oats as it appeared to suppress growth the most.

The pots were placed on movable trolleys and once a week pot positions were rotated within the tunnel. Data for dry weight were analysed using the analysis of variance (ANOVA) procedure in the statistical package Genstat (Payne et al., 2007). Treatment means were compared using Fisher's Protected Least Significant Difference procedure $\mathrm{P} \leq 0.05$.

\section{Results}

\section{Field experiment}

The main effects of treatment and season on the final maize emergence percentages counted on day seven were significantly different (Table 1). The two cover crop treatments suppressed maize emergence equally and significantly more than any other treatments. Significantly higher plant populations occurred in the non-residue treatments. Significantly lower plant populations were measured in 2005 and 2007 compared to 2003 and 2006.

Despite this, the response to the treatments was consistent over all years.

Table 1 Influence of annual ryegrass, stooling rye and weed residues on the percentage emergence of the maize seeds (Field experiment)

\begin{tabular}{lccccc}
\hline Treatment & $\mathbf{2 0 0 3}$ & $\mathbf{2 0 0 5}$ & $\mathbf{2 0 0 6}$ & $\mathbf{2 0 0 7}$ & Mean \\
\hline Weeds & 92.1 & 63.9 & 86.4 & 69.7 & $\mathbf{7 8 . 0} \mathbf{~ b}$ \\
Annual ryegrass & 77.5 & 37.2 & 78.4 & 49.4 & $\mathbf{6 0 . 6} \mathbf{~}$ \\
Stooling rye & 84.7 & 49.7 & 80.0 & 51.8 & $\mathbf{6 6 . 5} \mathbf{~ c}$ \\
Hand-weeded & 93.3 & 73.6 & 93.1 & 83.5 & $\mathbf{8 5 . 9} \mathbf{~ a}$ \\
Herbicide & 95.5 & 72.7 & 94.7 & 86.4 & $\mathbf{8 7 . 3} \mathbf{~ a}$ \\
Mean & $\mathbf{8 8 . 6} \mathbf{a}$ & $\mathbf{5 9 . 4} \mathbf{c}$ & $\mathbf{8 6 . 5} \mathbf{a}$ & $\mathbf{6 8 . 1} \mathbf{b}$ & \\
\hline SED for season & $\mathbf{3 . 8 1}$ & & & & \\
SED for treatment & $\mathbf{3 . 6 6}$ & & & & \\
\hline
\end{tabular}

Means followed by the same letter are not significantly different at $\mathrm{P} \leq 0.05$ 
The relationship between the maize seedling dry weight gain and time, as influenced by the different treatments averaged over the four seasons, is shown in Figure 1. Maize growth was relatively similar during the first two weeks of growth. Thereafter, the seedling growth increase was higher in non-residue treatments compared to the residue treatments. Maize growth was more suppressed in the annual ryegrass residues than the stooling rye and non-weeded control residues.

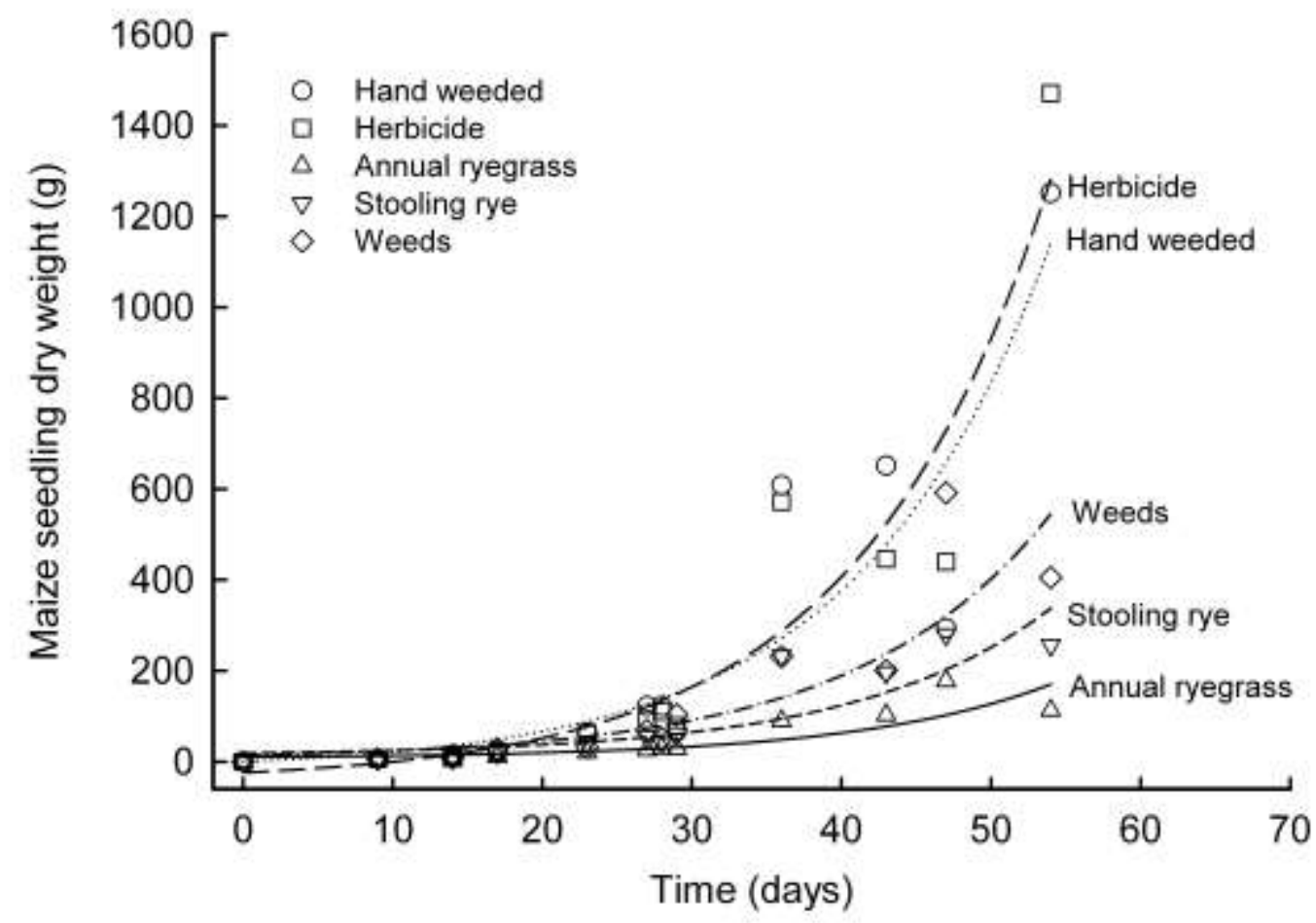

Figure 1 Relationship between the maize seedling dry weight gain and time as influenced by different treatments averaged over four seasons. (Adjusted $\mathrm{R}^{2}=84.90, \mathrm{Y}^{\text {Weeds }}=6.25+8.42 \mathrm{e}^{(0.077 \mathrm{x})}, \mathrm{Y}^{\mathrm{Rye}}=13.73+5.06 \mathrm{e}^{(0.077 \mathrm{x})}$, $\mathrm{Y}^{\text {Ryegrass }}=7.83+2.54 \mathrm{e}^{(0.077 \mathrm{x})}$, $\left.\mathrm{Y}^{\text {Hand-weeded }}=-18.25+18.12 \mathrm{e}^{(0.077 \mathrm{x})}, \mathrm{Y}^{\text {Herbicide }}=-44.79+20.74 \mathrm{e}^{(0.077 \mathrm{x})}\right)$

Comparisons of $C$. esculentus dry weight collected in the intra-row maize planting lines indicated that it was only at 16 DAE that significantly different amounts of $C$. esculentus leaf material accrued among the treatments (Table 2). At 28 DAE stooling rye residues significantly suppressed $C$. esculentus leaf growth (orthogonal contrast) compared to the non-weeded control, but suppression by annual ryegrass residues was not significant. 
Table 2 C. esculentus leaf dry weight gain $\left(\mathrm{t} \mathrm{ha}^{-1}\right)$ in maize intra-row planting lines at three sampling stages after the emergence of maize (Field experiment)

\begin{tabular}{lccc}
\hline Treatment & 16 DAE & 28 DAE & 41 DAE \\
\hline Weeds & $1.02 \mathrm{a}$ & $1.87 \mathrm{a}$ & $2.94 \mathrm{a}$ \\
Annual ryegrass & $0.62 \mathrm{ab}$ & $1.67 \mathrm{a}$ & $2.82 \mathrm{a}$ \\
Stooling rye & $0.53 \mathrm{~b}$ & $1.23 \mathrm{a}$ & $2.14 \mathrm{a}$ \\
\hline SED & $\mathbf{0 . 1 9}$ & $\mathbf{0 . 3 4}$ & $\mathbf{0 . 5 1}$ \\
\hline
\end{tabular}

DAE denotes days after emergence

Means followed by the same letter within a sampling stage are not significantly different by orthogonal contrast at $\mathrm{P} \leq 0.05$

The residues of both cover crop species significantly reduced $C$. esculentus growth in the maize inter-row planting lines compared to the non-weeded control at 16 and 28 DAE (Table 3). At 41 DAE, only stooling rye residues had significantly reduced C. esculentus growth.

Table 3 C. esculentus leaf dry weight $\left(\mathrm{t} \mathrm{ha}^{-1}\right)$ gain in maize inter-row planting lines at three sampling stages after the emergence of maize (Field experiment)

\begin{tabular}{lccc}
\hline Treatment & 16 DAE & 28 DAE & 41 DAE \\
\hline Weeds & $0.74 \mathrm{a}$ & $1.23 \mathrm{a}$ & $2.18 \mathrm{a}$ \\
Annual ryegrass & $0.17 \mathrm{~b}$ & $0.65 \mathrm{~b}$ & $1.54 \mathrm{ab}$ \\
Stooling rye & $0.30 \mathrm{~b}$ & $0.74 \mathrm{~b}$ & $1.19 \mathrm{~b}$ \\
\hline SED & $\mathbf{0 . 1 4}$ & $\mathbf{0 . 1 6}$ & $\mathbf{0 . 3 8}$ \\
\hline
\end{tabular}

DAE denotes days after emergence

Means followed by the same letter within a sampling stage are not significantly different by orthogonal contrast at $\mathrm{P} \leq 0.05$

Yield of the maize was significantly higher in the hand-weeded and herbicide treatments compared to the residue treatments (Table 4). Stooling rye had higher yields in 2006 compared to the non-weeded control and annual ryegrass with yields in the non-weeded control and annual ryegrass being similar. Maize yields in 2007 were lower in the three residue treatments with no significant differences among them. 
Table 4 Yield $\left(\mathrm{t} \mathrm{ha}^{-1}\right)$ of maize growing in two non-residue treatments and in weed, annual ryegrass and stooling rye residues (Field experiment)

\begin{tabular}{|c|c|c|c|c|}
\hline Treatment & 2003 & 2004 & 2006 & 2007 \\
\hline Weeds & $6.31 \mathrm{a}$ & $2.56 \mathrm{~b}$ & $3.11 \mathrm{~b}$ & $2.18 \mathrm{~b}$ \\
\hline Annual ryegrass & $2.18 \mathrm{c}$ & $2.30 \mathrm{~b}$ & $3.01 \mathrm{~b}$ & $1.98 \mathrm{~b}$ \\
\hline Stooling rye & $4.20 \mathrm{~b}$ & $2.02 \mathrm{~b}$ & $4.76 \mathrm{ab}$ & $3.10 \mathrm{~b}$ \\
\hline Hand-weeded & $8.22 \mathrm{a}$ & $8.50 \mathrm{a}$ & $6.52 \mathrm{a}$ & $7.31 \mathrm{a}$ \\
\hline Herbicide & $7.36 \mathrm{a}$ & $9.01 \mathrm{a}$ & 5.93 a & $6.90 \mathrm{a}$ \\
\hline SED for season*treatment & 1.218 & & & \\
\hline SED for means within season & 0.968 & & & \\
\hline
\end{tabular}

Means followed by the same letter are not significantly different at $\mathrm{P} \leq 0.05$

\section{Pot experiment}

Emergence of the maize plants in the roots treatment for all the cover crops was relatively similar to the soaked leaf material and control treatments (Table 5). Maize emergence was more suppressed in the leaf+root treatment compared to the others. Maize seedling emergence in the leaf+root treatment of the annual ryegrass cultivars Midmar and Sophia, was generally more inhibited compared to the oats, stooling rye and the annual ryegrass cultivar Agriton.

Table 5 Influence of different residue types of oats, stooling rye and three cultivars of annual ryegrass on the final emergence percentage of maize (Pot experiment)

\begin{tabular}{lccccc}
\hline \multicolumn{1}{l}{ Oats } & Stooling rye & \multicolumn{3}{c}{ Annual ryegrass } \\
Treatments & & & Agriton & Midmar & Sophia \\
\hline Leaf+root & $83.66 \mathrm{c}-\mathrm{e}$ & $85.00 \mathrm{~b}-\mathrm{e}$ & $85.00 \mathrm{~b}-\mathrm{e}$ & $74.00 \mathrm{fg}$ & $70.00 \mathrm{~g}$ \\
Roots & $96.00 \mathrm{a}$ & $95.00 \mathrm{ab}$ & $92.00 \mathrm{a}-\mathrm{d}$ & $89.00 \mathrm{a}-\mathrm{e}$ & $83.30 \mathrm{~d}-\mathrm{f}$ \\
Leaf material & $79.79 \mathrm{ef}$ & $90.00 \mathrm{a}-\mathrm{d}$ & $92.00 \mathrm{a}-\mathrm{d}$ & $97.00 \mathrm{a}$ & $92.00 \mathrm{a}-\mathrm{d}$ \\
Soaked leaf material & $94.22 \mathrm{ab}$ & $95.00 \mathrm{ab}$ & $94.00 \mathrm{ab}$ & $96.82 \mathrm{a}$ & $88.00 \mathrm{a}-\mathrm{e}$ \\
Control & & & $93.00 \mathrm{a}-\mathrm{c}$ & & \\
\hline SED & & $\mathbf{4 . 8 8}$ & & \\
\hline
\end{tabular}

Means followed by the same letter are not significantly different at $\mathrm{P} \leq 0.05$

The growth of maize was severely inhibited by the leaf+root and roots treatments of all the cover crop species (Table 6) while growth in the soaked leaf material was generally significantly better compared to control and leaf material. No significant differences in 
growth were measured amongst the different cover crop species in the leaf+root and roots treatments. The root and leaf material of the annual ryegrass cultivars Agriton and Midmar were more suppressive towards maize growth.

The growth of $C$. esculentus was severely inhibited in the leaf+root and roots treatments while the dry weight in the leaf material treatment was also less than the control (Table 7). No significant differences in dry weight were observed amongst the different cover crop species in the leaf+root and roots treatments. In the leaf material treatment, the three annual ryegrass cultivars significantly inhibited growth compared to the oats and stooling rye. Regardless of the overnight soaking of the leaf material of annual ryegrass cultivar 'Midmar', C. esculentus growth was still significantly inhibited compared to the soaked leaf material of the other cover crops.

Table 6 Influence of different residue types of oats, stooling rye and three cultivars of annual ryegrass on the dry weight per plant $(\mathrm{g})$ of maize seedlings (Pot experiment)

\begin{tabular}{lcccccc}
\hline & Oats & Stooling rye & \multicolumn{4}{c}{ Annual ryegrass } \\
Treatments & \multicolumn{2}{c}{} & & Agriton & Midmar & Sophia \\
\hline Leaf+root & $0.07 \mathrm{f}$ & $0.09 \mathrm{f}$ & $0.10 \mathrm{f}$ & $0.08 \mathrm{f}$ & $0.08 \mathrm{f}$ \\
Roots & $0.11 \mathrm{ef}$ & $0.13 \mathrm{ef}$ & $0.09 \mathrm{f}$ & $0.09 \mathrm{f}$ & $0.13 \mathrm{ef}$ \\
Leaf material & $0.62 \mathrm{c}$ & $0.53 \mathrm{c}$ & $0.28 \mathrm{~d}$ & $0.22 \mathrm{de}$ & $0.56 \mathrm{c}$ \\
Soaked leaf material & $0.81 \mathrm{~b}$ & $0.84 \mathrm{ab}$ & $0.86 \mathrm{ab}$ & $0.60 \mathrm{c}$ & $0.94 \mathrm{a}$ \\
Control & & & $0.60 \mathrm{c}$ & & & \\
\hline SED & & & &
\end{tabular}

$\begin{array}{lc}\text { SED } & 0.058\end{array}$

Means followed by the same letter are not significantly different at $\mathrm{P} \leq 0.05$

Table 7 Influence of different residue types of oats, stooling rye and three cultivars of annual ryegrass on the dry weight per plant (g) of C. esculentus (Pot experiment)

\begin{tabular}{lccccc}
\hline & Oats & Stooling rye & \multicolumn{3}{c}{ Annual ryegrass } \\
Treatments & & & Agriton & Midmar & Sophia \\
\hline Leaf+root & $0.02 \mathrm{~g}$ & $0.02 \mathrm{~g}$ & $0.03 \mathrm{fg}$ & $0.01 \mathrm{~g}$ & $0.02 \mathrm{~g}$ \\
Roots & $0.03 \mathrm{fg}$ & $0.03 \mathrm{fg}$ & $0.02 \mathrm{~g}$ & $0.02 \mathrm{~g}$ & $0.03 \mathrm{fg}$ \\
Leaf material & $0.16 \mathrm{e}$ & $0.14 \mathrm{e}$ & $0.08 \mathrm{f}$ & $0.08 \mathrm{f}$ & $0.06 \mathrm{fg}$ \\
Soaked leaf material & $0.31 \mathrm{ab}$ & $0.26 \mathrm{bc}$ & $0.25 \mathrm{c}$ & $0.18 \mathrm{de}$ & $0.33 \mathrm{a}$ \\
Control & & & $0.22 \mathrm{~cd}$ & & \\
\hline SED & & $\mathbf{0 . 0 2 8 6}$ & \\
\hline
\end{tabular}

Means followed by the same letter within a season are not significantly different at $\mathrm{P} \leq 0.05$ 
The leachate obtained from the root treatment for ryegrass cultivar Midmar tested positive for three out of the four allelochemicals targeted, followed by oats and ryegrass 'Sophia' with two out of four (Table 8). Midmar had the highest concentrations of benzoxazolin-2(3H)-one (BOA) and hydoxybenzoic acid compared to the other root treatments, and slightly less ferulic acid than oats. All three annual ryegrass cultivars exude the allelochemical BOA through their roots, with Midmar and Sophia containing hydroxybenzoic acid as well. The root leachate of oats contained ferulic acid and BOA. Vanillic acid was not detected in any of the root leachate of any of the cover crops.

Table 8 Concentrations (ppb) of phenolic acids and benzoxazolin-2(3H)-one (BOA) in the root material of oats and three annual ryegrass cultivars (Pot experiment)

\begin{tabular}{lcccc}
\hline & Vanillic acid & Ferulic acid & Hydroxybenzoic acid & BOA \\
\hline Oats & 0 & 16 & 0 & 7 \\
Annual ryegrass & 0 & 0 & 0 & 5 \\
cv. Agriton & 0 & 14 & 440 & 20 \\
cv. Midmar & 0 & 0 & 15 & 4 \\
cv. Sophia & & & \\
\hline
\end{tabular}

\section{Discussion}

Plant residues on the soil surface can reduce crop emergence through mechanical resistance, reduced light reaching the soil surface and due to interference with heat and water transfer between the soil and atmosphere (Teasdale et al., 2007). Contrasting results were obtained from the present field and pot experiments. In the field experiment, as planting furrows were devoid of cover crop residues because of the furrows being drawn with a v-shaped hoe, the growth inhibition could not have been due to a physical constraint contributed by the residues. If, hypothetically, the cover crop residues were present in the planting furrows, light should not have been a limitation to maize seedling emergence. Crops with big seeds seem to be less affected by the presence of residues than those with small seeds, because of the relatively large amount of resources available in the larger seeds (Teasdale, 1993). In the pot experiment this was confirmed since maize emergence was not suppressed by the presence of leaf residues on the soil surface. 
It is possible that fluctuations in soil temperature and moisture over the four seasons in the field experiment could have contributed to the reductions in crop emergence (Kravchenko \& Thelen, 2007), as soil temperature could have been lower and soil moisture higher under the residue. However, lower soil temperatures measured in the pots with residues on the soil surface (data not shown) did not influence emergence as it was similar between pots with and without residues, suggesting that temperature variations were not responsible for differences in emergence.

In both the field and pot experiments it was the cover crop species, rather than the amount of residues, that impaired maize seedling emergence as maize emergence was more suppressed by the annual ryegrass compared to the other treatments. Burgos and Talbert, (1996) reported similar results when the number of southern pea (Vigna unguiculata (L). Walp) plants was reduced in annual ryegrass residues, despite the latter crop's residues having had a similar amount of biomass to oats and a lower amount of biomass compared to sorghum-sudangrass (Sorghum bicolour L. Moench x Sorghum vulgare Pers. var. sudanense (Piper) Hitchc).

Investigations on the effect of cover crop residues on crop and weed emergence revealed the involvement of possible allelochemicals (Sicker et al., 2004). Benzoxazinones and various phenolic compounds have been identified in stooling rye (Wójcik-Wojtkowiak et al., 1990; Sicker et al., 2004). Benzoxazolin-2(3H)-one (BOA) inhibited the emergence of cucumbers (Chase et al., 1991) and radish (Raphanus sativus L.) (Chiapusio et al., 2004) while Einhellig (2004) reported on the various plant functions being influenced by phenolic acids. Results from the pot experiment showed that the emergence of the maize in the soaked leaf material treatment was better than in the leaf+root treatment, which is similar to the field situation, indicating that inhibition due to the presence of allelochemicals is a possibility.

Seedling growth after emergence can be influenced by the nutrient dynamics in the soil. $\mathrm{N}$ mineralization is dependent on various factors, among others the $\mathrm{C}: \mathrm{N}$ ratio of the residues (Kuo \& Jellum, 2002). The C:N ratio of cereals is mostly dependant on the total dry matter produced and the time of desiccation (Reeves, 1994) which could be higher than 25:1, at which stage $\mathrm{N}$ immobilization would occur. In addition, $\mathrm{N}$ immobilization is generally greater if the residues are incorporated (Smith \& Sharpley, 1990). Applying N at the beginning of the growth of the main crop can reduce the initial $\mathrm{N}$ deficiency (Reeves et al., 1990). The residues in the field experiment were not incorporated and additional $\mathrm{N}$ was 
applied at planting, thereby reducing the probability that $\mathrm{N}$ immobilization could have suppressed maize growth and the subsequent yields. Nutrient analysis from the seedlings growing in the pots and the leachate collected also indicated no nutrient deficiencies which could have inhibit growth.

Another contributing factor to the difference in maize growth amongst the treatments in the field experiment could have been the interference from $C$. esculentus. One hundred $C$. esculentus shoots $/ \mathrm{m}^{2}$ have the ability to reduce maize growth by $8 \%$. If the weed is not controlled from the beginning, the yield reduction can be as high as $41 \%$, with an initial infestation of 1200 shoots $/ \mathrm{m}^{2}$ (Stoller et al., 1979). Results from the field experiment, however, indicated that competition from C. esculentus did not have the expected impact on maize growth 14 DAE. Both the non-weeded control and annual ryegrass residues had relatively similar numbers of $C$. esculentus plants growing in the intra-row maize planting lines but maize seedlings continued to grow better in the non-weeded control than in the annual ryegrass treatment.

Reasons for the greater growth of $C$. esculentus material in the intra-row maize planting lines could have been the sprouting of $C$. esculentus tubers after soil disturbance during maize planting and the absence of residues in the lines not having presented a physical barrier to emergence. The non-weeded control had the lowest quantity of residues on the soil surface which could explain the higher $C$. esculentus dry weight measured in this treatment, both in the intra- and inter-row maize planting lines, supporting the conclusion that, compared with cover crops, annual weed residues do not suppress weed growth adequately (Liebl et al., 1992). Residues which are left on the soil surface suppress weed growth due to the physical constraint, although, C. esculentus leaves have sharp tips that could penetrate hard surfaces (Stoller \& Sweet 1987). The longer suppression effect of stooling rye on $C$. esculentus growth could possibly be due to the longer decomposition period of the coarser stooling rye compared to annual ryegrass (Masiunas et al., 1995).

Results from the pot experiment showed that treatments containing root material caused greater growth inhibitions compared to the leaf treatments. According to Snaydon and Howe (1986) ryegrass interference with wheat primarily takes place below ground. Breland (1996) concluded that the suppression of grain establishment after the incorporation of fresh annual ryegrass material was due to phytotoxic substances. Chemical analysis of the root 
leachate indicated that more allelochemicals at higher concentrations were present in the root leachate of the ryegrass cultivar Midmar compared to the other treatments albeit in low concentrations. Differences in the allelochemical content amongst cultivars is well known (Reberg-Horton et al., 2009). The allelopathic effect on plants is often the result of a combination of these chemicals released together, as individual compounds are often present in concentrations below their inhibition thresholds (Inderjit \& Nayyar, 2002).

We conclude that the different cover crop species, cultivars and residue type affected maize and C. esculentus growth differently and that during the decomposition of root residues of annual ryegrass in the field, putative allelochemicals were excreted which suppressed early C. esculentus growth. It however also compromised maize seedling growth and, together with the competition from C. esculentus later in the season, led to the lower maize yields. Therefore the null hypothesis, stating that the cover crop residues would control C. esculentus with no influence on maize, must be rejected. However, findings suggest that the concept of using cover crop residues for weed suppression still holds merit. C. esculentus growth was restricted during early maize growth and if weed competition later in the season can be reduced by post-emergence herbicides, the effect on maize growth can conceivably be limited. It is therefore possible to reduce the number of herbicide applications thereby contributing to lower input costs. Reduction of recommended herbicide rates is not advised as a means of saving on input costs. Due to the fact that the allelopathic effect from the residues is dependent on soil and climatic factors, it is foreseeable that the implementation of this practice would probably be limited, especially in the case of small-scale farmers, as it will require additional management skills. Future research should involve a wider range of cover crop species and different residue management practices.

\section{Acknowledgements}

This study is part of a Ph.D thesis submitted in the Department of Plant Production and Soil Science, University of Pretoria, South Africa.

\section{References}

BRELAND TA (1996) Phytotoxic effects of fresh and decomposing cover crop residues. Norwegian Journal of Agricultural Sciences 10, 355-362. 
BURGOS NR \& TALBERT RE (1996) Weed control by spring cover crops and imazethapyr in notill southern pea (Vigna unguiculata). Weed Technology 10, 893-899.

CHASE WR, NAIR MG, \& PUTNAM AR (1991) 2,2`-Oxo-1,1'-azobenzene: selective toxicity of rye (Secale cereale L.) allelochemicals to weed and crop species: II. Journal of Chemical Ecology 17, 9-19.

CHIAPUSIO G, PELLISSIER F, \& GALLET C (2004) Uptake and translocation of phytochemical 2benzoxazolinone (BOA) in radish seeds and seedlings. Journal of Experimental Botany $\mathbf{5 5}$, 1587-1592.

CREAMER NG, BENNET MA, STINNER BR, CARDINA J, \& REGNIER EE (1996) Mechanisms of weed suppression in cover crop-based production systems. HortScience 31, 410-413.

DHIMA KV, VASILAKOGLOU IB, ELEFTHEROHORINOS IG, \& LITHOURGIDIS AS (2006) Allelopathic potential of winter cereals and their cover crop mulch effect on grass suppression and corn development. Crop Science 46, 345-352.

DROST DC \& DOLL JD (1980) The allelopathic effect of yellow nutsedge (Cyperus esculentus) on corn (Zea mays) and soybean (Glycine max). Weed Science 28, 229-233.

EINHELLIG FA (2004) Mode of Allelochemical Action of Phenolic Compounds. In: Allelopathy: chemistry and mode of actions of allelochemicals (eds. FA Macìas, JCG Galindo, JMG Molinillo, \& HG Cutler), 217-238. CRC Press, Boca Raton.

FERREIRA MI \& REINHARDT CF (2010) Field assessment of crop residues for allelopathic effects on both crops and weeds. Agronomy Journal 102, 1593-1600.

FOURIE JC, LOUW PJE, \& AGENBAG GA (2006) Cover crop management in a Chardonnay/99 Richter vineyard in the coastal wine grape region, South Africa. 1. Effect of two management practices on selcted grass and broadleaf species. South African Journal of Enology and Viticulture 27, 167-177.

HALFORD C, HAMILL AS, ZHANG J, \& DOUCET C (2001) Critical period of weed control in notill soybean (Glycine max) and corn (Zea mays). Weed Technology 15, 737-744.

INDERJIT \& NAYYAR H (2002) Shift in Allelochemical Functioning With Selected Abiotic Stress Factors. In: Chemical ecology of plants: allelopathy in aquatic and terrestrial ecosystems (eds. Inderjit \& AU Mallik), 199-218. Birkhäuser Verlag, Switzerland.

JOHNSON III WC \& MULLINIX JR BG (1999) Cyperus esculentus interference in Cucumis sativus. Weed Science 47, 327-331.

KRAVCHENKO AG \& THELEN CD (2007) Effect of winter wheat crop residue on no-till corn growth and development. Agronomy Journal 99, 549-555.

KRUIDHOF HM, BASTIAANS L, \& KROPFF MJ (2008) Ecological weed management by cover cropping: effects on weed growth in autumn and weed establishment in spring. Weed Research 48, 492-592. 
KUO S \& JELLUM EJ (2002) Influence of winter cover crop and residue management on soil nitrogen availability and corn. Agronomy Journal 94, 501-508.

LI B, SHIBUYA T, YOGO Y, HARA T, \& MATSUO K (2001) Effects of light quantity and quality on growth and reproduction of a clonal sedge Cyperus esculentus. Plant Species Biology 6981.

LIEBL R, SIMMONS FW, WAX LM, \& STOLLER EW (1992) Effect of rye (Secale cereale) mulch on weed control and soil moisture in soybean (Glycine max). Weed Technology 6, 838-846.

LITTLE KM \& VAN STADEN J (2003) Interspecific competition affects early growth of a Eucalyptus grandis x E. camaldulensis hybrid clone in Zululand, South Africa. South African Journal of Botany 69, 505-513.

MASIUNAS JB, WESTON LA, \& WELLER SC (1995) The impact of rye cover crops on weed populations in a tomato cropping system. Weed Science 43, 318-323.

MOFFETT JE \& MCCLOSKEY WB (1998) Effects of soil moisture and yellow nutsedge (Cyperus esculentus) density on cotton (Gossypium hirsutum). Weed Science 46, 231-237.

NAIR MG, WHITENACK CJ, \& PUTNAM AR (1990) 2,2'-Oxo-1,1'-azobenzene: a microbially transformed allelochemical from 2,3-benzoxazolinone: I. Journal of Chemical Ecology 16, 353-364.

NORSWORTHY JK, MALIK MS, JHA P, \& RILEY MB (2007) Suppression of Digitaria sanguinalis and Amaranthus palmeri using autumn-sown glucosinolate-producing cover crops in organically grown bell peper. Weed Research 47, 425-432.

OLOFSDOTTER M, JENSEN LB, \& COURTOIS B (2002) Improving crop competitive ability using allelopathy - an example from rice. Plant Breeding 121, 1-9.

PAYNE RW, MURRAY DA, HARDING SA, BAIRD DB, \& SOUTAR DM (2007) GenStat for Windows VSN International Ltd, Hemel, Hampstead, United Kingdom.

REBERG-HORTON SC, BURTON JD, DANEHOWER DA et al. (2009) Changes over time in the allelochemical content of ten cultivars of rye (Secale cereale L.). Journal of Chemical Ecology 31, 179-193.

REEVES DW (1994) Cover Crops and Rotations. In: Advances in soil science: crops residue management (eds. JL Hatfield \& BA Stewart), 125-172. CRC Press, Boca Raton.

REEVES DW, EDWARDS JH, ELKINS CB, \& TOUCHTON JT (1990) In-row tillage methods for subsoil amendment and starter fertilizer application to conservation-tilled grain sorghum. Soil and Tillage Research 16, 359-369.

RYAN MR, MORTENSEN DA, BASTIAANS L et al. (2009) Elucidating the apparent maize tolerance to weed competition in long-term organically managed systems. Weed Research $\mathbf{5 0}$, 25-36.

SICKER D, HAO H, \& SCHULZ M (2004) Benzoxazolin - 2 (3H) -Ones Generation and Detoxification in Competition Among Plants. In: Allelopathy: chemistry and mode of action 
of allelochemicals (eds. FA Macìas, JCG Galindo, JMG Molinillo, \& HG Cutler), 1st edn, 77102. CRC Press, Boca Raton.

SMITH SJ \& SHARPLEY AN (1990) Soil nitrogen mineralization in the presence of surface and incorporated crop residues. Agronomy Journal 82, 112-116.

SNAYDON RW \& HOWE CD (1986) Root and shoot competition between established ryegrass and invading grass seedlings. Journal of Applied Ecology 23, 667-674.

STOLLER EW \& SWEET RD (1987) Biology and life cycle of purple and yellow nutsedge (Cyperus rotundus and Cyperus esculentus). Weed Technology 1, 66-73.

STOLLER EW, WAX LM, \& SLIFE FW (1979) Yellow nutsedge (Cyperus esculentus) competition and control in corn (Zea mays). Weed Science 27, 32-37.

TEASDALE JR (1993) Interaction of light, soil moisture and temperature with weed suppression by hairy vetch residue. Weed Science 41, 46-51.

TEASDALE JR, BRANDSÆTER LO, CALEGARI A, \& SKORA NETO F (2007) Cover Crops and Weed Management. In: Non-chemical weed management (eds. MK Upadhyaya \& RE Blackshaw), 49-64. CAB International, Oxfordshire.

TEASDALE JR \& MOHLER CL (2000) The quantitative relationship between weed emergence and the physical properties of mulches. Weed Science 48, 385-392.

VASILAKOGLOU IB, DHIMA KV, ELEFTHEROHORINOS IG, \& LITHOURGIDIS AS (2006)

Winter cereal cover crop mulches and inter-row cultivation effects on cotton development and grass weed suppression. Agronomy Journal 98, 1290-1297.

WÓJCIK-WOJTKOWIAK D, POLITYCKA B, SCHNEIDER M, \& PERKOWSKI J (1990) Phenolic substances as allelopathic agents arising during the degradation of rye (Secale cereale) tissues. Plant and Soil 124, 143-147. 